\title{
Effect of low dose ketamine to prevent remifentanil-induced cough: a randomized, double-blind, placebo controlled trial
}

\author{
Department of Anesthesiology and Pain Medicine, Anesthesia and Pain Research Institute, Yonsei University College of Medicine, Seoul, \\ *Department of Anesthesiology and Pain Medicine, Ajou University College of Medicine, Suwon, \\ ${ }^{\dagger}$ Gachon University of Medicine and Science, Gil Medical Center, Incheon, Korea
}

Ji Young Kim, Jong-Yeop Kim*, Sung Yong Park*, Wol Seon Jung ${ }^{\dagger}$, and Hyun-Jeong Kwak ${ }^{\dagger}$

Background: A reflex cough is often observed after an intravenous (IV) bolus of remifentanil. Since ketamine was reported to be effective in modulating the cough reflex, this prospective, randomized, double-blind, placebo-controlled study was designed to evaluate the efficacy of pretreatment with ketamine on remifentanil-induced cough.

Methods: 320 patients undergoing general anesthesia for elective surgery were randomly allocated into two groups to receive either IV ketamine $0.1 \mathrm{mg} / \mathrm{kg}$ (ketamine group, $\mathrm{n}=156$ ) or $0.9 \%$ saline (saline group, $\mathrm{n}=154$ ) 1 min before administration of remifentanil at a target effect-site concentration of $5 \mathrm{ng} / \mathrm{ml}$. Severity of cough was graded (mild, 1-2; moderate, 3-4; and severe, 5 or $>5$ ).

Results: The overall incidence of cough was significantly higher in the saline group (43/154 patients; $0.28,95 \%$ CI 0.21 , $0.36)$ than that in the ketamine group $(18 / 156$ patients; $0.12,95 \%$ CI $0.07,0.18)(\mathrm{P}<0.001)$. However, there was no significant difference in the severity and the onset time of cough between the groups.

Conclusions: IV ketamine $0.1 \mathrm{mg} / \mathrm{kg}$ one minute before remifentanil was effective in suppressing remifentanil-induced cough without affecting the severity and onset time. (Korean J Anesthesiol 2009; 56: 624 7)

Key Words: Ketamine, Opioid-induced cough, Remifentanil.

\section{INTRODUCTION}

Remifentanil has favorable pharmacokinetic properties with rapid onset and offset of action, which makes it appropriate adjunct during anesthesia induction to provide cardiovascular stability and intense analgesia. However, a small dose of intravenous remifentanil elicits cough, as any other opioid of fentanyl series [1]. Based on previous studies, the incidence of remifentanil-induced cough was higher than that of fentanyl-induced cough $[1,2]$. The prevention of opioid-induced cough has

Received: March 23, 2009.

Accepted: April 22, 2009.

Corresponding author: Hyun-Jeong Kwak, M.D., Department of Anesthesiology and Pain Medicine, Gachon University of Medicine and Science, Gil Medical Center, Guwol-dong, Namdong-gu, Incheon 405-220, Korea. Tel: 82-32-4603637, Fax: 82-32-469-6319, E-mail: hyun615@gilhospital.com

Copyright (C) Korean Society of Anesthesiologists, 2009

(c) This is an open-access article distributed under the terms of the Creative Commons Attribution License, which permits unrestricted use, distribution, and reproduction in any medium, provided the original work is properly cited. an important clinical implication because opioid associated cough can be severe enough to cause multiple conjunctival and periorbital petechia, which may have resulted form increased intracranial, intra-ocular, and intra-abdominal pressure $[3,4]$. The increase in intraoculr or intracranial pressure can be devastating to patients with glaucoma or a space occupying lesion in the brain. The need to reduce cough during opioid injection has encouraged many different approaches using local anesthetics, ketamine, selective $\beta$-agonist and many others with varying results [1,5-9].

$\mathrm{N}$-methyl-D-aspartate (NMDA) receptor was reported to play a critical role in the modulation of the cough reflex [10]. Therefore, the purpose of this study was to evaluate the efficacy of pretreatment with ketamine, an NMDA receptor antagonist, on remifentanil-induced cough.

\section{MATERIALS AND METHODS}

This study was approved by the institutional review board and written informed consent for the study was obtained from 
all patients. Three hundred and twenty patients, ASA physical status I or II, aged 18-65 years, undergoing general anesthesia for elective surgery, were studied. Patients were randomly allocated to either control or ketamine group using computer generated randomization list generated by a statistician in a sealed envelope. The exclusion criteria included body weight exceeding $20 \%$ of the ideal body weight, a history of bronchial asthma or chronic obstructive pulmonary disease, respiratory tract infection, hypertension treated with angiotensin converting enzyme inhibitors, and the use of psychoactive drugs.

No premedication was administered before surgery. Before arrival in the operating room, a 20 -gauge cannula was inserted in the dorsum of the hand and connected to a T-connector for drug injection. An independent researcher prepared study syringe for each patient. Anesthesiologists were blinded to the patient group. On arrival in the operating room, all patients were monitored with electrocardiogram, pulse oximeter, noninvasive blood pressure, and capnography. One min before remifentanil administration, patients received either IV ketamine $0.1 \mathrm{mg} / \mathrm{kg}$ (diluted with normal saline to $1 \mathrm{mg} / \mathrm{ml}$ ) or equal volume of $0.9 \%$ saline $(0.1 \mathrm{ml} / \mathrm{kg})$ over $5 \mathrm{sec}$ according to their group. Remifentanil was administered at a target effect-site concentration of $5 \mathrm{ng} / \mathrm{ml}$ via target-controlled infusion (TCI) pump (Orchestra ${ }^{\circledR}$, Fresenius Vial, France). After IV remifentanil infusion, the onset time (from the start of TCI to the beginning of coughing) and severity of cough were observed for $1 \mathrm{~min}$ and recorded by an observer who was blinded to the type of medication given to the patients. Severity of coughing was graded based on the number of episodes of cough (mild, 1-2; moderate, 3-4; and severe, 5 or $>5$ ). Assisted mask ventilation with oxygen was applied if desaturation was observed $\left(\mathrm{SpO}_{2}<90 \%\right)$. The incidences of apnea, truncal rigidity, and psychomimetic symptoms were also recorded. Apnea was defined as a pause in breathing for more than 15 seconds and truncal rigidity as increased large trunk muscle tone, which renders facemask ventilation difficult or impossible. Any unpleasant symptoms including dissociative feelings ("elevator" effect), alertness disturbances (somnolence or insomnia) or sensory changes (taste changes, numbness, tingling, hot, cold) were considered as psychomimetic symptoms. Mean arterial pressure (MAP), heart rate (HR), and $\mathrm{SpO}_{2}$ were recorded on arrival in the operating room (baseline) and $1 \mathrm{~min}$ after remifentanil infusion. Authors hypothesized that the incidence of cough during remifentanil injection would be re- duced with pretreatment of an NMDA antagonist, ketamine. Therefore, the primary outcome was the reduction of the incidence of cough and the secondary outcome was the severity of cough.

Considering the incidence of remifentanil-induced cough was 27\% [1] and assuming a decrease in the incidence of cough to half of control after ketamine treatment, this study required at least 152 patients per group at the 5\% level of significance and $80 \%$ power of test. Considering $5 \%$ drop out rate, 320 patients were randomized in this study.

Statistical analyses were performed with the statistical package (SPSS 13.0 for windows, SPSS Inc, Chicago, IL, USA). Data are presented as mean \pm SD or number of patients. Patients' characteristics, the difference of onset time to cough and hemodynamic variables between groups were compared with Student's t-test. Incidence of coughing was analyzed with chi-square test. A P value $<0.05$ was considered statistically significant.

\section{RESULTS}

Four patients in ketamine group and 6 patients in saline group did not complete the study due to intravenous line obstruction. There was no significant difference in patient characteristics between the two groups (Table 1). The overall incidence of cough was significantly higher in the saline group (43/154 patients; $0.28,95 \%$ CI $0.21,0.36)$ than that in the ketamine group (18/156 patients; $0.12,95 \%$ CI $0.07,0.18)(\mathrm{P}<$ $0.001)$. However, there was no significant difference in the severity and the onset time of cough between the groups. In the ketamine group, 18 patients had cough and 10, 4, and 4 of those patients had mild, moderate, and severe cough, respectively. This was similar to the saline group in which 23 ,

Table 1. Patients' Characteristics and Remifentanil Dose

\begin{tabular}{lcc}
\hline & $\begin{array}{c}\text { Ketamine } \\
(\mathrm{n}=156)\end{array}$ & $\begin{array}{c}\text { Saline } \\
(\mathrm{n}=154)\end{array}$ \\
\hline Sex $(\mathrm{M} / \mathrm{F})$ & $87 / 69$ & $83 / 71$ \\
Age (years) & $39.0 \pm 12.9$ & $37.3 \pm 11.9$ \\
Weight $(\mathrm{kg})$ & $64.6 \pm 11.1$ & $65.7 \pm 11.2$ \\
Height $(\mathrm{cm})$ & $166.0 \pm 8.9$ & $166.9 \pm 8.7$ \\
Smoker & $47(30.1 \%)$ & $51(33.1 \%)$ \\
ASA physical status $(\mathrm{I} / \mathrm{II})$ & $127 / 29$ & $130 / 24$ \\
Remifentanil dose $(\mu \mathrm{g})$ & $80.2 \pm 6.6$ & $80.8 \pm 6.5$ \\
\hline
\end{tabular}

Values are mean $\pm \mathrm{SD}$ or number of patients. 
Table 2. Incidence of Cough, Severity of Cough, and Onset Time after Remifentanil Infusion

\begin{tabular}{lcccccc}
\hline \multirow{2}{*}{ Group } & \multirow{2}{*}{ No cough } & \multicolumn{5}{c}{ Incidence and severity of cough } \\
\cline { 3 - 6 } & & Total & Mild & Moderate & Severe & Onset (s) \\
\hline Ketamine $(\mathrm{n}=156)$ & $138^{\mathrm{a})} / 156$ & $18 / 156(11.5 \%)$ & $10 / 18(55.5 \%)$ & $4 / 18(22.2 \%)$ & $4 / 18(22.2 \%)$ & $26.8 \pm 5.7$ \\
Saline $(\mathrm{n}=154)$ & $111 / 154$ & $43 / 154(27.9 \%)$ & $23 / 43(53.5 \%)$ & $12 / 43(27.9 \%)$ & $8 / 43(18.6 \%)$ & $24.3 \pm 6.1$ \\
\hline
\end{tabular}

Values are number of patients or mean $\pm \mathrm{SD}$. ${ }^{\text {a) }} \mathrm{P}<0.001$ compared with saline group.

Table 3. Mean Arterial Pressure and Heart Rate during Anesthesia Induction

\begin{tabular}{llcc}
\hline & \multicolumn{1}{c}{ Group } & Baseline & $\begin{array}{c}1 \text { min after } \\
\text { remifentanil } \\
\text { infusion }\end{array}$ \\
\hline MAP (mmHg) & Ketamine $(\mathrm{n}=134)$ & $96.1 \pm 13.7$ & $97.8 \pm 12.9$ \\
& Saline $(\mathrm{n}=140)$ & $98.3 \pm 11.9$ & $94.9 \pm 12.8^{\mathrm{a})}$ \\
HR (beats/min) & Ketamine $(\mathrm{n}=134)$ & $75.0 \pm 15.0$ & $\left.76.8 \pm 17.3^{\mathrm{a}}\right)$ \\
& Saline $(\mathrm{n}=140)$ & $72.3 \pm 15.6$ & $74.1 \pm 17.9^{\mathrm{a})}$ \\
\hline
\end{tabular}

Values are mean \pm SD. MAP: mean arterial blood pressure, HR: heart rate. ${ }^{\mathrm{a})} \mathrm{P}<0.05$ compared with baseline value.

12, and 8 of 43 patients who coughed had mild, moderate, and severe cough, respectively (Table 2). No patient complained psycomimetic symptoms in the ketamine group during anesthesia induction.

Hemodynamic data were lost in 22 and 14 patients in ketamine and saline group, respectively. MAP and HR during anesthesia induction are listed in Table 3. MAP at $1 \mathrm{~min}$ after remifentanil infusion in saline group was significantly decreased from the baseline value. In the both groups, HR was significantly increased significantly $1 \mathrm{~min}$ after remifentanil infusion compared with baseline. None of the patients suffered from hypoxemia, desaturation, apnea, truncal rigidity, or other adverse effects.

\section{DISCUSSION}

This study demonstrated that when remifentanil was administered at target effect-site concentration of $5 \mathrm{ng} / \mathrm{ml}$, pretreatment of intravenous ketamine $0.1 \mathrm{mg} / \mathrm{kg}$ reduced the incidence of remifentanil-induced cough from $27.9 \%$ to $11.5 \%$ ( $\mathrm{P}<0.001$ ). However, its severity and onset time was unaffected $(\mathrm{P}>0.05)$.

Several reports using different drugs have been recently published to prevent the opioid-induced cough [1,5-9]. Most of them were on the fentanyl-induced cough. Although various mechanisms responsible for opioid-induced cough have been postulated, the exact mechanism is still unclear. Opioid could inhibit central sympathetic outflow, therefore activating the vagus nerve. This enhancement of vagal activity was reported as a possible cause of cough and reflex bronchoconstriction $[7,11,12]$. Other possible mechanisms postulated as the cause of opioid-induced cough include pulmonary chemoreflex, which is mediated by either rapidly adapting irritant receptors or vagal C-fiber receptors located in proximity to pulmonary vessels $[13,14]$, and the trigger stimulus and bronchial hyperirritability theory $[7,12]$.

Ketamine is a noncompetitive NMDA receptor antagonist and NMDA receptor was suggested to be involved in regulation of cough reflex [10]. Experimental studies have demonstrated that remifentanil activated NMDA receptor but fentanyl did not $[15,16]$. The incidence of remifentanil-induced cough in this study was higher than that of fentanyl-induced cough (27.9\% vs. $8 \%$ respectively) [2]. This higher incidence of cough with remifentanil may be explained by the difference in the stimulation of NMDA receptors. Ketamine may attenuate reflex bronchoconstriction or cough through the blockade of NMDA receptor activation, which result in the direct or indirect bronchodilating effects on airway smooth muscle $[3,17]$. Bongianni et al [18] reported in anesthetized rabbits that microinjection of NMDA receptor antagonists into the caudal part of ventral respiratory group suppressed the inspiratory and expiratory components of cough reflex. Previous study using small dose lidocaine $(0.5 \mathrm{mg} / \mathrm{kg})$ reported that there was a significant reduction in the incidence of cough (absolute risk reduction, 12.4\%; relative risk reduction, 44.9\%) [1]. In this study using $0.1 \mathrm{mg} / \mathrm{kg}$ of ketamine, the risk reduction was greater than the study with lidocaine since there was significant reduction in the incidence rate of cough from $27.9 \%$ to $11.5 \%$ (absolute risk reduction, $16.4 \%$; relative risk reduction, 60.4\%). Ketamine was administered $1 \mathrm{~min}$ before remifentanil infusion because ketamine has the rapid onset of action with peak concentration occurring within $1 \mathrm{~min}$ after IV administration. The dose of ketamine $(0.1 \mathrm{mg} / \mathrm{kg})$ in this study 
was based on a previous study by Yeh et al $(0.15 \mathrm{mg} / \mathrm{kg})$ [5]. The dose was reduced to decrease the side-effects of ketamine.

As for the hemodynamic effect of ketamine during anesthesia induction, there were significant differences in MAP and $\mathrm{SpO}_{2}$, but it was clinically insignificant because no patients had showed a MAP above $120 \mathrm{~mm} \mathrm{Hg}$ or $\mathrm{SpO}_{2}<90 \%$. Furthermore, MAP in ketamine group did not change $1 \mathrm{~min}$ after remifentanil infusion, whereas that in the saline group was significantly decreased. These results are consistent with a previous study by Koo et al [19].

In conclusion, administration of IV ketamine $0.1 \mathrm{mg} / \mathrm{kg}$ one minute before remifentanil was effective in suppressing remifentanil-induced cough without affecting the severity and onset time.

\section{REFERENCES}

1. Kim JY, Park KS, Kim JS, Park SY, Kim JW. The effect of lidocaine on remifentanil-induced cough. Anaesthesia 2008; 63: 495-8.

2. Lin JA, Yeh CC, Lee MS, Wu CT, Lin SL, Wong CS. Prolonged injection time and light smoking decrease the incidence of fentanyl-induced cough. Anesth Analg 2005; 101: 670-4.

3. Phua WT, Teh BT, Jong W, Lee TL, Tweed WA. Tussive effect of a fentanyl bolus. Can J Anaesth 1991; 38: 330-4.

4. Tweed WA, Dakin D. Explosive coughing after bolus fentanyl injection. Anesth Analg 2001; 92: 1442-3.

5. Yeh CC, Wu CT, Huh BK, Lee MS, Lin SL, J Sheen M, et al. Premedication with intravenous low-dose ketamine suppresses fentanyl-induced cough. J Clin Anesth 2007; 19: 53-6.

6. Horng $\mathrm{HC}$, Wong CS, Hsiao KN, Huh BK, Kuo CP, Cherng CH, et al. Pre-medication with intravenous clonidine suppresses fentanyl-induced cough. Acta Anaesthesiol Scand 2007; 51: 862-5.

7. Agarwal A, Azim A, Ambesh S, Bose N, Dhiraj S, Sahu D, et al. Salbutamol, beclomethasone or sodium chromoglycate suppress coughing induced by iv fentanyl. Can J Anaesth 2003; 50:
297-300.

8. Lin CS, Sun WZ, Chan WH, Lin CJ, Yeh HM, Mok MS. Intravenous lidocaine and ephedrine, but not propofol, suppress fentanyl-induced cough. Can J Anaesth 2004; 51: 654-9.

9. Pandey CK, Raza M, Ranjan R, Singhal V, Kumar M, Lakra A, et al. Intravenous lidocaine $0.5 \mathrm{mg} / \mathrm{kg}$ effectively suppresses fentanyl-induced cough. Can J Anaesth 2005; 52: 172-5.

10. Kamei J, Tanihara H, Igarashi $\mathrm{H}$, Kasuya $\mathrm{Y}$. Effects of N-methyl-D-aspartate antagonists on the cough reflex. Eur J Pharmacol 1989; 168: 153-8.

11. Reitan JA, Stengert KB, Wymore ML, Martucci RW. Central vagal control of fentanyl-induced bradycardia during halothane anesthesia. Anesth Analg 1978; 57: 31-6.

12. Lui $\mathrm{PW}$, Hsing $\mathrm{CH}$, Chu YC. Terbutaline inhalation suppresses fentanyl-induced coughing. Can J Anaesth 1996; 43: 1216-9.

13. Böhrer H, Fleischer F, Werning P. Tussive effect of a fentanyl bolus administered through a central venous catheter. Anaesthesia 1990; 45: 18-21.

14. Paintal AS. Mechanism of stimulation of type $\mathrm{J}$ pulmonary receptors. J Physiol 1969; 203: 511-32.

15. Guntz E, Dumont H, Roussel C, Gall D, Dufrasne F, Cuvelier L, et al. Effects of remifentanil on N-methyl-D-aspartate receptor: an electrophysiologic study in rat spinal cord. Anesthesiology 2005; 102: $1235-41$.

16. Hahnenkamp K, Nollet J, Van Aken HK, Buekle H, Halene T, Schaurte S, et al. Remifentanil directly activates human N-methyl-D-aspartate receptors expressed in Xenopus laevis oocytes. Anesthesiology 2004; 100: 1531-7.

17. Haxhiu MA, Deal EC Jr, Norcia MP, van Lunteren E, Cherniack NS. Effect of N-methyl-D-aspartate applied to the ventral surface of the medulla on the trachea. J Appl Physiol 1987; 63: 1268-74.

18. Bongianni F, Mutolo D, Nardone F, Pantaleo T. Ionotropic glutamate receptors mediate excitatory drive to caudal medullary expiratory neurons in the rabbit. Brain Res 2005; 1056: 145-57.

19. Koo SW, Cho SJ, Kim YK, Ham KD, Hwang JH. Small-dose ketamine reduces the pain of propofol injection. Anesth Analg 2006; 103: $1444-7$. 